\title{
Association between screen time and behavioural health problems among urban and rural students in early and mid-adolescent age group
}

\author{
Ilamparithi $\mathbf{P}^{1}$, Selvakumar $\mathbf{P}^{2}$ \\ ${ }^{1}$ Dr. Ilamparithi P, Junior Resident, ${ }^{2}$ Dr. Selvakumar P, Associate Professor; both authors are affiliated with \\ Department of Pediatrics, Thanjavur Medical College, Thanjavur, Tamil Nadu, India
}

Address for Correspondence: Dr. Selvakumar P,180,9 $9^{\text {th }}$ Cross, Arulananda Nagar Extension, Thanjavur, Tamilnadu. E-Mail: drselva_kumar69@yahoo.co.in

\begin{abstract}
Objective: To estimate screen time and determine the association of screen time and behavioural health problems among urban and rural students in early and mid-adolescent age group. Method: design: analytical questionnaire based cross sectional study. Study settings: Rural and urban schools in Thanjavur. Participants: 200 students in early and mid-adolescent age group with equal distribution from urban and rural schools. Procedure: A student's questionnaire to quantify screen time and Strengths and Difficulties Questionnaire (SDQ) completed by the student, teacher and parents was used to identify behavioural health problems. Statistical analysis: Degree of association (Odd's ratio) was used to find the association between screen time and behavioural problems. Results: Average screen time was $6.59 \pm 1.24 \mathrm{hrs}$ in urban boys, $3.28 \pm 0.17 \mathrm{hrs}$ in rural boys, $4.28 \pm 0.49 \mathrm{hrs}$ in urban girls $\& 4.07 \pm 0.44 \mathrm{hrs}$ in rural girls. When screen time exceeded 2 hours, there was increased association with emotional problems in rural boys, whereas conduct problem, hyperactivity/inattention, peer and pro-social problems were more in urban boys. Among girls, association with conduct problems was noted in rural girls, whereas hyperactivity and peer problems were found in urban girls. Conclusion: The average screen time in early and mid adolescents exceed the currently recommended duration of 2 hours/day and is associated with behavioural health problems.
\end{abstract}

Key words: Screen time, Strengths and Difficulty Questionnaire, Behavioural problems

\section{Introduction}

In the last decade, with technological advancement, there is a dramatic increase in the availability and use of electronic gadgets such as, smart phones, computers, video game consoles and tablets.

The time spent on television, Internet and videogames, which is collectively known as screen time, is increasing among today's youth [1-3]. The National Kaiser Family Foundation (US) survey (2010) found that children aged 8 to 18 years had an

Manuscript received: $04^{\text {th }}$ July 2017

Reviewed: $12^{\text {th }}$ July 2017

Author Corrected: $18^{\text {th }}$ July 2017

Accepted for Publication: $30^{\text {th }}$ July 2017 average screen time of 7.5 hours/day [4]. This has glaringly exceeded the American Academy of Pediatrics (AAP) recommendation of 2 hours or less [5]. There is no such data from India.

Excessive exposure to screens especially at adolescence has been associated with lower academic performance, increased sleep problems, obesity, behavioural problems, increased aggression, lower self-esteem and depression. This study was conducted to estimate the screen time in Indian adolescents and find out the association between the screen time and behavioural health problems. 


\section{Methods}

This analytical cross-sectional study was performed between January 2017 and May 2017 in Thanjavur, Tamilnadu. Four schools were selected randomly: 2 from the corporation limits (urban) and 2 from villages

(rural). Two hundred subjects of class 8 and 9 were selected by multistage stratified random sampling, of which 100 were from urban schools and 100 from rural schools with equal gender distribution. The students who were all present on that particular day of study in the school were included. The sample size was calculated by using www.openepi.com with confidence interval of $95 \%$ (alpha $=95 \%$ ), power as $80 \%$ and ratio of exposed with unexposed as 1 . The odds ratio of 11 was assumed from the previous study with $5 \%$ of unexposed with outcome. The final sample size achieved per group was 52 and hence total of 208. Considering a $10 \%$ dropout, the final sample size was $228(208+20=228)$. The achieved sample size at the end of the study was only 200 . This is because of non-responsiveness and logistic reasons.

The achieved sample size 200 was tested for the power. The post-hoc power analysis were found to be adequate $(\beta=88 \%)$. All schools participated out of intrinsic motivation and not for any incentive. Students and teachers were informed of the purpose of the study and the content of the questionnaire and their consent for participation obtained. The students independently completed the confidential questionnaire on screen time and the Strengths and Difficulties Questionnaire [6] (SDQ), in English/Tamil, for age 11 to 17 years in classroom settings in the presence of a research assistant. The SDQ is a widely used survey instrument with higher validity and reliability. The SDQ completed by the respective teachers were collected on the same day. The SDQ for parents were sent in sealed envelopes and the response obtained the next day. The SDQ contains 5 scales for measuring conduct problems, hyperactivity/inattention, peer relationship problems, emotional symptoms and pro-social behaviour. The pro-social behaviour was assigned a separate score and a total difficulty score was calculated by summing up the scores of the other 4 scales. Data sheets from all the participants were complete (no missing data).

Table-1: SDQ scoring values

\begin{tabular}{|c|c|c|c|}
\hline & Normal & Borderline & Abnormal \\
\hline 1.Emotional symptoms score & $0-5$ & 6 & $7-10$ \\
\hline 2.Conduct problems score & $0-3$ & 4 & $5-10$ \\
\hline 3.Hyperactivity score & $0-5$ & 6 & $6-10$ \\
\hline 4.Peer problems score & $0-4$ & 5 & $0-4$ \\
\hline 5.Pro-social behaviour score & $6-10$ & 5 & $20-40$ \\
\hline Total difficulties score(1+2+3+4) & $0-15$ & $16-19$ & \\
\hline
\end{tabular}

From the questionnaire on screen time, the amount of time spent watching TV/DVD and using a computer/ game console was calculated as hours/day. Screen time was assessed separately for week days and weekends. The total screen time was calculated by obtaining the mean time for devices for both week days and weekends. The method used in this study to measure the child screen time was similar to those in peer reviewed research [7,8]. Institutional Ethics Committee approved this study.

Statistical Analysis: The groups were compared using one way ANOVA and unpaired t test. Non-parametric data were analysed using Mann-Whitney $U$ test and Kruskal-Wallis test wherever appropriate. Association was analysed using Spearman'es test. The data were analysed using the software Graphpad Prism V.5.0.

\section{Results}

Two hundred students aged 13 to 15 years consisting of 100 boys and 100 girls attending 2 rural and 2 urban schools participated in the study. Socio- demographic characteristics are listed in table 2. 
Table-2: Socio-demographic characters

\begin{tabular}{|c|c|c|c|c|c|}
\hline Sl. No & Characteristic & $\begin{array}{c}\text { Rural } \\
(n=100)\end{array}$ & $\begin{array}{c}\text { Urban } \\
(n=100)\end{array}$ & p value & $\begin{array}{c}\text { Statistical Test } \\
\text { Applied }\end{array}$ \\
\hline \multirow[t]{3}{*}{1} & Age in years & & $($ Mean \pm SD $)$ & & \\
\hline & Boys & $14.4 \pm 0.67$ & $13.1 \pm 0.6$ & $<0.0001$ & \multirow[t]{2}{*}{ Mann-Whitney Test } \\
\hline & Girls & $13.8 \pm 0.47$ & $12.9 \pm 0.58$ & $<0.0001$ & \\
\hline \multirow[t]{11}{*}{2} & \multicolumn{4}{|c|}{ Parents Education (\%) } & \\
\hline & \multicolumn{4}{|c|}{ Father } & \\
\hline & $<10^{\text {th }}$ standard & $83 \%$ & $25 \%$ & $<0.0001$ & \\
\hline & HSC & $16 \%$ & $3 \%$ & 0.0028 & \multirow[t]{3}{*}{ Fisher's Exact test } \\
\hline & Undergraduate & $1 \%$ & $53 \%$ & $<0.0001$ & \\
\hline & Post graduate & $0 \%$ & $19 \%$ & $<0.0001$ & \\
\hline & \multicolumn{4}{|c|}{ Mother } & \\
\hline & $<10^{\text {th }}$ standard & $86 \%$ & $25 \%$ & $<0.0001$ & \multirow[t]{4}{*}{ Fisher's Exact test } \\
\hline & HSC & $12 \%$ & $19 \%$ & NS (0.329) & \\
\hline & Undergraduate & $2 \%$ & $34 \%$ & $<0.0001$ & \\
\hline & Postgraduate & $0 \%$ & $22 \%$ & $<0.0001$ & \\
\hline 3 & $\begin{array}{c}\text { Occupational } \\
\text { state: Both employed }\end{array}$ & $56 \%$ & $\%$ & 0.0045 & Chi square test \\
\hline \multirow[t]{3}{*}{4} & \multicolumn{4}{|c|}{ Type of family } & \\
\hline & Nuclear & $84 \%$ & $77 \%$ & $\mathrm{NS}(0.2116)$ & Chi square test \\
\hline & Joint & $16 \%$ & $23 \%$ & NS (0.2842) & \\
\hline
\end{tabular}

HSC - Higher secondary; NS - Not significant.

Comparison of screen time in urban and rural adolescents is shown in Table 3 and Figure 1

Table 3: Comparison of screen time in rural and urban adolescents

\begin{tabular}{|c|c|c|c|c|c|}
\hline $\begin{array}{l}\text { SI. } \\
\text { No }\end{array}$ & $\begin{array}{l}\text { Parameter } \\
\text { (in hour) }\end{array}$ & $\begin{array}{l}\text { Rural } \\
(n=100)\end{array}$ & $\begin{array}{l}\text { Urban } \\
(n=100)\end{array}$ & p value & Confidence interval \\
\hline \multirow[t]{3}{*}{1} & \multicolumn{3}{|c|}{ Weekdays screen time(Mean \pm SEM $)$} & & \\
\hline & Boys & $15.08 \pm 1.07$ & $29.4 \pm 6.44$ & 0.03 & 1.344 to 27.29 \\
\hline & Girls & $18.3 \pm 2.15$ & $17.9 \pm 2.28$ & NS (0.905) & -6.606 to 5.866 \\
\hline \multirow[t]{3}{*}{2} & \multicolumn{5}{|c|}{ Weekend screen time } \\
\hline & Boys & $7.8 \pm 0.4$ & $16.79 \pm 2.36$ & 0.0004 & 4.115 to 13.67 \\
\hline & Girls & $10.2 \pm 1.18$ & $12.05 \pm 1.47$ & NS (0.3259) & -1.883 to 5.611 \\
\hline \multirow[t]{3}{*}{3} & \multicolumn{2}{|c|}{ Average screen time } & & & \\
\hline & Boys & $3.28 \pm 0.17$ & $6.59 \pm 1.24$ & 0.0095 & 0.8277 to 5.803 \\
\hline & Girls & $4.07 \pm 0.44$ & $4.28 \pm 0.49$ & NS (0.747) & -1.096 to 1.522 \\
\hline
\end{tabular}

$\mathrm{NS}=$ Not significant; $\mathrm{SEM}=$ Standard error of mean 
Footnote: Weekdays (WD) and weekend (WE) screen time (ST) were calculated by multiplying the daily screen time with 5 and 2 respectively. The average screen time was calculated by the formula: average screen time $=$ $[($ WD ST $\times 5)+($ WE ST $\times 2)] / 7$. Unpaired t test was used to compare the means of both the groups and $\mathrm{p}<0.05$ was considered statistically significant.

The weekdays and weekend screen time was significantly higher in urban boys than rural boys, while no difference was observed in the girls. When average screen time was considered in respect to gender, the trend remains the same.

Figure-1: Comparison of screen time between different groups.

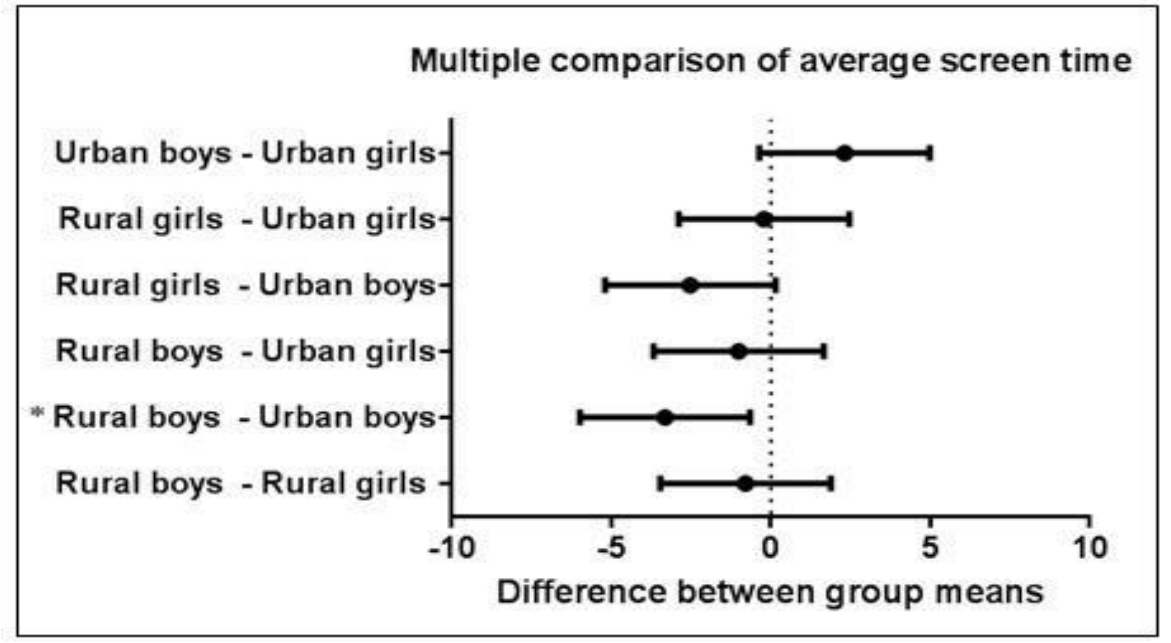

${ }^{*}$ p value $<0.05$ is statistically significant

Data are expressed as mean (dot) with 95\% confidence interval (whiskers). One-way ANOVA with Bonferroni post hoc test was used for the analysis.

Pattern of use of screen with food and in bedroom are given in table 4

Table- 4: Pattern of use of "screens" with food and at bed time in various study groups

\begin{tabular}{|c|c|c|c|c|c|c|c|c|c|c|}
\hline \multirow{2}{*}{$\begin{array}{l}\text { Sl. } \\
\text { No }\end{array}$} & \multirow[t]{2}{*}{ Parameter } & \multicolumn{2}{|l|}{ Rural } & \multirow{2}{*}{$\begin{array}{l}p \\
\text { Value }\end{array}$} & \multicolumn{2}{|l|}{ Urban } & \multirow[t]{2}{*}{ p value } & \multicolumn{2}{|c|}{ Overall usage } & \multirow[t]{2}{*}{ p value } \\
\hline & & $\begin{array}{l}\text { Boys } \\
(n=50)\end{array}$ & $\begin{array}{l}\text { Girls } \\
(\mathrm{n}=50)\end{array}$ & & $\begin{array}{l}\text { Boys } \\
(n=50)\end{array}$ & $\begin{array}{l}\text { Girls } \\
(n=50)\end{array}$ & & $\begin{array}{l}\text { Rural } \\
(n=100)\end{array}$ & $\begin{array}{l}\text { Urban } \\
(n=100)\end{array}$ & \\
\hline & \multicolumn{10}{|c|}{ Use of "screen" with food } \\
\hline \multirow[t]{3}{*}{1} & Yes & $\begin{array}{l}41 \\
(82 \%)\end{array}$ & $\begin{array}{l}35 \\
(70 \%)\end{array}$ & \multirow[t]{2}{*}{$\begin{array}{l}\text { NS } \\
(0.214)\end{array}$} & $\begin{array}{l}37 \\
(74 \%)\end{array}$ & $\begin{array}{l}42 \\
(84 \%)\end{array}$ & \multirow[t]{2}{*}{$\begin{array}{l}\text { NS } \\
(0.326)\end{array}$} & $\begin{array}{l}76 \\
(76 \%)\end{array}$ & $\begin{array}{l}79 \\
(79 \%)\end{array}$ & \multirow[t]{2}{*}{$\begin{array}{l}\text { NS } \\
(0.735)\end{array}$} \\
\hline & No & $9(18 \%)$ & $\begin{array}{l}15 \\
(30 \%)\end{array}$ & & $\begin{array}{l}13 \\
(26 \%)\end{array}$ & $8(16 \%)$ & & $\begin{array}{l}24 \\
(24 \%)\end{array}$ & $\begin{array}{l}21 \\
(21 \%)\end{array}$ & \\
\hline & \multicolumn{10}{|c|}{ Use of Screen in bedroom } \\
\hline \multirow[t]{2}{*}{2} & Yes & $\begin{array}{l}32 \\
(64 \%)\end{array}$ & $\begin{array}{l}24 \\
(48 \%)\end{array}$ & \multirow[t]{2}{*}{$\begin{array}{l}\text { NS } \\
(0.158)\end{array}$} & $\begin{array}{l}32 \\
(64 \%)\end{array}$ & $\begin{array}{l}21 \\
(42 \%)\end{array}$ & \multirow[t]{2}{*}{0.041} & $\begin{array}{l}56 \\
(56 \%)\end{array}$ & $\begin{array}{l}53 \\
(53 \%)\end{array}$ & \multirow[t]{2}{*}{$\begin{array}{l}\text { NS } \\
(0.776)\end{array}$} \\
\hline & No & $\begin{array}{l}18 \\
(36 \%)\end{array}$ & $\begin{array}{l}26 \\
(52 \%)\end{array}$ & & $\begin{array}{l}18 \\
(36 \%)\end{array}$ & $\begin{array}{l}29 \\
(58 \%)\end{array}$ & & $\begin{array}{l}44 \\
(44 \%)\end{array}$ & $\begin{array}{l}47 \\
(47 \%)\end{array}$ & \\
\hline
\end{tabular}

$\mathrm{p}<0.05$ is considered statistically significant. NS $=$ Not significant.

There was no significant difference in use of screen in bedroom and with food among rural boys and girls. Gender made a difference only in the urban group, where boys reported a significantly higher screen usage in bedroom ( $\mathrm{p}$ $=0.04)$. 
Sleep duration of children in rural and urban groups are given in Table 5

Table-5: Sleep duration of children in rural and urban groups

\begin{tabular}{|c|c|c|c|c|c|c|c|c|c|c|}
\hline \multirow{2}{*}{$\begin{array}{l}\text { Sl. } \\
\text { No }\end{array}$} & \multirow[b]{2}{*}{$\begin{array}{l}\text { Sleep } \\
\text { duration } \\
\text { in hours } \\
\text { (Mean } \pm \\
\text { SD) }\end{array}$} & \multicolumn{2}{|l|}{ Rural } & \multirow{2}{*}{$\begin{array}{l}p \\
\text { Value }\end{array}$} & \multicolumn{2}{|l|}{ Urban } & \multirow[t]{2}{*}{ p value } & \multicolumn{2}{|c|}{ Overall usage } & \multirow[t]{2}{*}{ p value } \\
\hline & & $\begin{array}{l}\text { Boys } \\
(n=50)\end{array}$ & $\begin{array}{l}\text { Girls } \\
(n=50)\end{array}$ & & $\begin{array}{l}\text { Boys } \\
(n=50)\end{array}$ & $\begin{array}{l}\text { Girls } \\
(n=50)\end{array}$ & & $\begin{array}{l}\text { Rural } \\
(n=100)\end{array}$ & $\begin{array}{l}\text { Urban } \\
(n=100)\end{array}$ & \\
\hline 1 & $\begin{array}{l}\text { All } \\
\text { Weedayds }\end{array}$ & $\begin{array}{l}40.9 \pm \\
9.5\end{array}$ & $\begin{array}{l}43.9 \pm \\
5.2 \\
\end{array}$ & $\begin{array}{l}\text { NS } \\
(0.55)\end{array}$ & $\begin{array}{l}39.3 \pm \\
8.01 \\
\end{array}$ & $\begin{array}{l}36.1 \pm \\
13.1 \\
\end{array}$ & $\begin{array}{l}\text { NS } \\
(0.144)\end{array}$ & $\begin{array}{ll}42.4 & \pm \\
7.8 & \\
\end{array}$ & $\begin{array}{ll}37.7 & \pm \\
10.9 & \\
\end{array}$ & 0.0006 \\
\hline 2 & Weekend & $\begin{array}{l}18.1 \pm \\
4.8\end{array}$ & $\begin{array}{l}19.4 \pm \\
2.5\end{array}$ & $\begin{array}{l}\text { NS } \\
(0.09)\end{array}$ & $\begin{array}{l}18 \pm \\
3.6\end{array}$ & $\begin{array}{l}17.4 \pm \\
6.6\end{array}$ & $\begin{array}{l}\text { NS } \\
(0.54)\end{array}$ & $\begin{array}{ll}18.7 \quad \pm \\
3.8\end{array}$ & $\begin{array}{ll}17.6 \quad \pm \\
5.3\end{array}$ & $\begin{array}{l}\mathrm{NS} \\
(0.109)\end{array}$ \\
\hline 3 & $\begin{array}{l}\text { Average } \\
\text { per day in } \\
\text { a Week }\end{array}$ & $\begin{array}{l}8.4 \pm \\
1.9\end{array}$ & $\begin{array}{l}9.04 \pm \\
0.9\end{array}$ & $\begin{array}{l}\text { NS } \\
(0.051)\end{array}$ & $\begin{array}{l}8.1 \pm \\
1.3\end{array}$ & $\begin{array}{l}7.6 \pm \\
2.7\end{array}$ & $\begin{array}{l}\text { NS } \\
(0.21)\end{array}$ & $\begin{array}{ll}8.73 \quad \pm \\
1.5 & \end{array}$ & $7.9 \pm 2.1$ & 0.0024 \\
\hline
\end{tabular}

Non-parametric t test was used to test the level of significant differences between the groups.

$\mathrm{p}<0.05$ is considered as statistically significant.

There was no significant difference in sleep duration between genders in both urban and rural population. However when rural and urban groups were compared irrespective of gender, urban children were observed to have significantly less sleep duration than the rural children on weekdays $(p=0.0006)$ while the same was not observed on weekend.

The odds ratio of association between screen time and behavioural problems between gender and type of population are shown in table 6

Table-6: Odds ratio of association between Screen time and behavioural problems.

\begin{tabular}{|c|c|c|c|c|c|}
\hline & & Screen time $>2$ & & & \\
\hline \multirow[t]{2}{*}{ Sl. No } & \multirow[t]{2}{*}{ Parameter } & \multicolumn{2}{|l|}{ Boys $(n=100)$} & \multicolumn{2}{|l|}{$\operatorname{Girls}(n=100)$} \\
\hline & & Rural & Urban & Rural & Urban \\
\hline 1 & $\begin{array}{l}\text { Emotional } \\
\text { Problems }\end{array}$ & $\begin{array}{l}13.57 \\
(0.739 \text { to } 249.1)\end{array}$ & $\begin{array}{l}5.57 \\
(0.29 \text { to } 106.1)\end{array}$ & $\begin{array}{l}2.0 \\
(0.48 \text { to } 8.8)\end{array}$ & $\begin{array}{l}4.4 \\
(0.23 \text { to } 87.6)\end{array}$ \\
\hline 2 & $\begin{array}{l}\text { Conduct } \\
\text { Problems }\end{array}$ & $\begin{array}{l}0.97 \\
(0.22 \text { to } 4.81)\end{array}$ & $\begin{array}{l}13.24 \\
(0.72 \text { to } 251.4)\end{array}$ & $\begin{array}{l}8.64 \\
(0.46 \text { to } 160.7)\end{array}$ & $\begin{array}{l}4.4 \\
(0.23 \text { to } 87.6)\end{array}$ \\
\hline 3 & $\begin{array}{l}\text { Hyperactivity \& } \\
\text { Inattention }\end{array}$ & $\begin{array}{l}0.7 \\
(0.02 \text { to } 18.62)\end{array}$ & $\begin{array}{l}9.01 \\
(0.48 \text { to } 166.4)\end{array}$ & $\begin{array}{l}2.1 \\
(0.09 \text { to } 46.58)\end{array}$ & $\begin{array}{l}8.1 \\
(0.43 \text { to } 152.7)\end{array}$ \\
\hline 4 & Peer problems & $\begin{array}{l}1.7 \\
(0.41 \text { to } 7.75)\end{array}$ & $\begin{array}{l}9.01 \\
(0.48 \text { to } 166.4)\end{array}$ & $\begin{array}{l}2.3 \\
(0.43 \text { to } 12.2)\end{array}$ & $\begin{array}{l}6.8 \\
(0.36 \text { to } 129.3)\end{array}$ \\
\hline 5 & $\begin{array}{l}\text { Pro-social } \\
\text { Problems }\end{array}$ & $\begin{array}{l}2.86 \\
(0.14 \text { to } 56.1)\end{array}$ & $\begin{array}{l}4.86 \\
(0.24 \text { to } 89.1)\end{array}$ & $\begin{array}{l}0.17 \\
(0.01 \text { to } 2.06)\end{array}$ & $\begin{array}{l}2.3 \\
(0.1 \text { to } 59.3)\end{array}$ \\
\hline
\end{tabular}

Data are expressed as Odds ratio value (95\% confidence interval). 
Among the rural boys, when the usage of screen time was more than 2 hours, there was 13.57 times increased association between screen time and emotional problems while only a weak association with other parameters was observed. In urban boys, 13.24 times increased association with conduct problems, 9.01 times increased association with hyperactivity and inattention, 9.01 times increased association with peer problems and 4.86 times increased association with pro-social problems were noted. There was weak association with emotional problems in urban boys when the screen time was more than 2 hours.

When screen time exceeded two hours in rural girls, there was 8.64 times increased association with conduct problems. Whereas in urban girls, there was increased association with conduct problems, hyperactivity and peer problems.

\section{Discussion}

Excessive screen time for more than 2 hours daily has been found to be associated with increased psychosocial problems, elevated blood pressure, elevated serum cholesterol and obesity among adolescents. The time spent on the screens significantly reduce a child's time for activities necessary for healthy development like playing, reading, storytelling and spending time with peers and family[9]. Further, screen time behaviour established in adolescent has been shown to track into adulthood. In a 2012 survey in U.S, only $27 \%$ of children aged 12-15 had two hours or less of television and computer use daily. In our study, the average screen time of adolescent boys and girls both in urban and rural regions was substantially higher than the recommended 2 hours. The screen time of urban boys was $(6.59 \pm 1.24$ hours $)$ which was significantly higher than that of rural boys $(3.28 \pm 0.07$ hours) in our study.

There are established association between screen time in youth and compromised sleep quantity (duration) and quality (night time waking, nightmares, irregular bed times) [10-12] as well as between variety of childhood behavioural health outcomes (internalizing, externalizing and peer problems)[13-15]. The relationship between use of electronic media and sleep problems are not well established. Several theories have been suggested for the same namely, bright light delaying the circadian rhythm [16], negative impact by electromagnetic radiation [10], physical discomfort such as muscular pain and headache due to prolonged media use [17] and media use interfering with sleep through increased psychological arousal and stimulation caused by either the content of the material or exposure to inherent intrinsic bright light [10]. In our study, sleep disturbances occurred more in urban children whose screen time was significantly higher than the rural children.

In SDQ survey done by Mathers et al. [18] and Vincent Busch et al. [19] association of hyperactivity with excessive internet usage was reported. They found no significant association of other psychosocial problems with internet usage. In our study, we found that there is an increased association between screen time and several behavioural health problems. There is an increased association of emotional problems in rural boys whereas psychosocial problems like conduct, hyperactivity, inattention, peer and pro-social problems association in urban students when screen time exceeded 2 hours.

Several studies have reported a strong association between television viewing and risk of developing obesity [20-22]. Children consume an extra 167 calories per day for every hour of television viewing [23].In our study $77.5 \%$ of children used screens while having food and $54.5 \%$ used screens in bedrooms. AAP recommends turning off the television while having food and not allowing adolescents to have television, computers and internet access in the bed room. In our study $68 \%$ of the parents did not follow a screen time policy while the AAP recommends appropriate time limit for use of social media.

\section{Conclusion}

In our study, the screen time in early and mid-adolescents exceed the currently recommended duration and is associated with behavioural health problems. The main strength of our study is that there are very few studies on 
screen time and association between screen exposure and behavioural health problems in Indian adolescents. The limitations of our study were non-inclusion of late adolescents and lack of definite differentiation of urban and rural students as the schools in both rural and urban areas would have mixed population. We assumed the proportion would

be very minimal in our region. Further studies involving large well defined population based sample of adolescents, with inclusion of several detailed measures of sleep pattern and sleep problems as well as detailed measures of media use are required for definitive recommendations

on screen time in our population.

\section{What Is Already Known?}

- $\quad$ Limited data on screen time in Indian adolescents.

What This Study Adds?

Funding: Nil, Conflict of interest: None initiated, Perission from IRB: Yes

\section{References}

1. Christakis DA. Internet addiction: a 21st century epidemic? BMC Med. 2010 Oct 18;8:61. doi: 10.1186/1741-7015-8-61.

2. Weinstein A, Lejoyeux M. Internet addiction or excessive internet use. Am J Drug Alcohol Abuse. $2010 \quad$ Sep;36(5):277-83. doi: $10.3109 / 00952990.2010 .491880$.

3. Tremblay MS, LeBlanc AG, Kho ME, Saunders TJ, Larouche R, Colley RC, Goldfield G, Connor Gorber S. Systematic review of sedentary behaviour and health indicators in school-aged children and youth. Int J Behav Nutr Phys Act. 2011 Sep 21;8:98. doi: 10.1186/1479-5868-8-98.

4. Generation M2: Media in the lives of 8-18 yearolds. The Henry.J Kaiser Family Foundation$\begin{array}{lll}\text { January } & 20 & \text { 2010.Available }\end{array}$ from:http://www.kff.org/entmedia/mh012010pkg.... Accessed June 202017

5. American Academy of Paediatrics-Committee on Public Education. Children, Adolescents and Television. Pediatrics 2001 Feb;107(2):4236.doi:10.1542/peds.107.2.423.
6. Goodman R. Psychometric properties of the strengths and difficulties questionnaire. J Am Acad Child Adolesc Psychiatry 2001 Nov;40(11):133745. doi:10.1097/00004583-200111000-00015.

7. Gingold JA, Simon AE, Schoendorf KC. Excess screen time in US children: association with family rules and alternative activities. Clin Pediatr (Phila). 2014 Jan;53(1):41-50. doi: 10.1177/0009922813498152. Epub 2013 Aug 5.

8. Sanders W, Parent J, Forehand R, Breslend NL. The roles of general and technology-related parenting in managing youth screen time. J Fam Psychol. 2016 Aug;30(5):641-6. doi: 10.1037/fam0000175. Epub 2016 Jan 11.

9. Canadian Paediatric Society, Healthy Active Living for Children and Youth Advisory Committee Healthy active living for children and youth. Paediatr Child Health. 2002 May- Jun;7(5):339-45.

10. Cain N, Gradisar M.Electronic media use and sleep in school-aged children and adolescents: A review. Sleep Med. 2010 Sep;11(8):735-42. doi: 10.1016/j.sleep.2010.02.006. Epub 2010 Jul 29.

11. Gradisar M, Short MA. Sleep hygiene and environment: the role of technology. In: Wolfson AR, Montgomery- Downs HE, editors. The Oxford handbook of Infant, Child, and Adolescent sleep and behavior. Oxford: Oxford University Press; 2013:113. 
12. Hale L, Guan S. Screen time and sleep among school-aged children and adolescents: a systematic literature review. Sleep Med Rev. 2015 Jun;21:50-8. doi: 10.1016/j.smrv.2014.07.007. Epub 2014 Aug 12.

13. Bagley E, El-Sheikh M. Children's sleep and internalizing and externalizing symptoms. In: Wolfson AR, Montgomery -Downs HE, editors. The Oxford Handbook of Infant, Child, and Adolescent sleep and behavior. Oxford: Oxford University Press; 2013:381-96.

14. El-Sheikh M, Sadeh A. I. Sleep and development: introduction to the monograph. Monogr Soc Res Child Dev. 2015 Mar;80(1):1-14. doi: $10.1111 /$ mono.12141.

15. Smedje H, Broman JE, Hetta J. Associations between disturbed sleep and behavioural difficulties in 635 children aged six to eight years: a study based on parents' perceptions. Eur Child Adolesc Psychiatry. 2001 Mar;10(1):1-9.

16. Khalsa SB, Jewett ME, Cajochen C, Czeisler CA. A phase response curve to single bright light pulses in human subjects. J Physiol 2003 Jun15;549(3):945-52.

doi:10.1113/physiol.2003.040477. EPub 2003 Apr 25

17. Thomee S, Dellve L, Harenstam A, Hagberg M. Perceived connections between information and communication technology use and mental symptoms among young adults - a qualitative study BMC Public Health 2010 Feb;10:66. doi:10.1186/1471-2458-10-60.

18. Mathers M, Canterford L, Olds T, Hesketh K, Ridley K, Wake M. Electronic media use and adolescent health and well-being: cross-sectional community study. Acad Pediatr. 2009 SepOct;9(5):307-14. doi: 10.1016/j.acap.2009.04.003. Epub 2009 Jul 9.

19. Busch V, Manders LA, de Leeuw JR. Screen time associated with health behaviors and outcomes in adolescents. Am J Health Behav. 2013 Nov;37(6):819-30. doi: 10.5993/AJHB.37.6.11.

20. Dietz WH Jr, Gortmaker SL. Do we fatten our children at the television set? Obesity and television viewing in children and adolescents. Pediatrics. 1985 May;75(5):807-12.

21. Robinson TN. Television viewing and childhood obesity. Pediatr Clin North Am. 2001 Aug;48(4):1017-25.

22. Kuriyan R, Bhat S, Thomas T, Vaz M, Kurpad AV. Television viewing and sleep are associated with overweight among urban and semi-urban South Indian children. Nutr J. 2007 Sep 20;6:25.

23. Wiecha JL, Peterson KE, Ludwig DS, Kim J, Sobol A, Gortmaker SL. When children eat what they watch: impact of television viewing on dietary intake in youth. Arch Pediatr Adolesc Med. 2006 Apr;160(4):436-42.

\section{How to cite this article?}

Ilamparithi P, Selvakumar P. Association between screen time and behavioural health problems among urban and rural students in early and mid-adolescent age group. J PediatrRes.2017;4(07):453-460. doi:10.17511/ijpr.2017.i07.04. 